\title{
Association between ambient carbon monoxide and secondary hyperparathyroidism in nondiabetic patients undergoing peritoneal dialysis
}

\author{
This article was published in the following Dove Press journal: \\ Therapeutics and Clinical Risk Management \\ 16 September 2015 \\ Number of times this article has been viewed
}

\author{
Cheng-Hao Weng ${ }^{1,2}$ \\ Ching-Chih $\mathrm{Hu}^{3}$ \\ Tzung-Hai Yen ${ }^{1,2}$ \\ Wen-Hung Huang ${ }^{1,2}$ \\ 'Department of Nephrology, \\ Division of Clinical Toxicology, \\ Chang Gung Memorial Hospital, \\ Linkou, ${ }^{2}$ College of Medicine, Chang \\ Gung University, Taoyuan, ${ }^{3}$ Liver \\ Research Unit, Department of \\ Hepatogastroenterology, Chang Gung \\ Memorial Hospital, Keelung, Taiwan
}

Correspondence: Wen-Hung Huang Department of Nephrology, Division of Clinical Toxicology, Chang Gung Memorial Hospital, Linkou, 5 Fu-Shing Street, Gueishan, Taoyuan 333, Taiwan Email williammedia@yahoo.com.tw

\begin{abstract}
Background: Secondary hyperparathyroidism (SHPT) is a major disorder in patients with chronic renal disease with or without dialysis. Air pollution has been confirmed as being associated with increased incidence of human morbidity and mortality. To our knowledge, investigating air pollution as a dialysis-unrelated factor for SHPT in patients undergoing dialysis is limited. We developed this study to assess the effect of air pollution and other important risk factors on SHPT in patients undergoing peritoneal dialysis (PD).
\end{abstract}

Materials and methods: We recruited a total of 141 patients who did not have diabetes mellitus, were nonsmokers, and were undergoing PD in this cross-sectional study. We analyzed the difference in air quality based on the patients' living areas. We estimated demographic, hematological, nutritional, inflammatory, biochemical, air pollutant, and dialysis-related data based on this cross-sectional study. Subgroup analysis of the relationship between air pollutants and the clinical variables and having or not having hyperparathyroidism (HPT) (intact parathyroid hormone level $\geq 180 \mathrm{pg} / \mathrm{dL}$ ) was also performed.

Results: A total of 141 patients undergoing PD (30 men and 111 women) were enrolled in the study. Sixty-eight patients had SHPT. In a binary logistic regression, high environmental CO exposure (odds ratio [OR] 3.22, 95\% confidence interval [CI] 1.42-7.28; $P=0.005$ ), serum phosphate levels (OR 1.66, 95\% CI 1.17-2.37; $P=0.005$ ), hypoalbuminemia (OR 3.76, 95\% CI 1.29-10.94; $P=0.015$ ), and use of calcitriol (OR 8.25, 95\% CI 3.43-19.85; $P<0.001$ ) were positively associated with SHPT.

Conclusion: The findings of this cross-sectional study indicated the presence of an association between environmental CO exposure and SHPT in patients undergoing PD who did not have diabetes mellitus. Therefore, poor environmental air quality may be a risk factor for deterioration of SHPT in patients undergoing PD.

Keywords: air pollution, $\mathrm{CO}$, carbon monoxide, hyperparathyroidism, peritoneal dialysis

\section{Introduction}

Chronic kidney disease (CKD), a global noncommunicable disease, is not only a medical but also a public health problem. ${ }^{1}$ Secondary hyperparathyroidism (SHPT), a common disorder in CKD and patients undergoing dialysis resulting from progressively impaired metabolism of calcium, phosphate, and vitamin $\mathrm{D}$, leads to abnormal bone and mineral metabolism. ${ }^{2,3}$ SHPT could be treated with vitamin D sterols, calcimimetics, and parathyroidectomy. In patients undergoing dialysis, with their calcium level corrected by dialysis and calcium supplements, the role of controlling the level of phosphate is more important for SHPT. Age, sex, diabetes mellitus (DM), dialysis duration, and hyperphosphatemia 
are associated with SHPT in patients undergoing dialysis. ${ }^{4}$ In 2002, Agarwal et al showed that children living in areas of high atmospheric pollution have high parathyroid hormone (PTH) levels. ${ }^{5}$ Recently, Hosseinpanah et al reported that the incidence of SHPT among women living in a polluted area was high. ${ }^{6}$ In these studies, they did not show which air pollutants were associated with SHPT. To our knowledge, investigations are limited regarding air pollution as a dialysisunrelated factor for SHPT in patients undergoing peritoneal dialysis (PD). The aim of this cross-sectional survey was to assess the role of air pollution and other clinical variables on SHPT in patients undergoing PD.

\section{Materials and methods}

This cross-sectional study complied with the guidelines of the Declaration of Helsinki and was approved by the Medical Ethics Committee of Chang Gung Memorial Hospital, a medical center in the northern part of Taiwan. Because this was a retrospective cross-sectional design, no informed consent was needed. In addition, all patients' information was securely protected (by delinking identifying information from the main data set) and was available to investigators only. Furthermore, all patients' records or information were anonymized and deidentified before analysis. All the data were analyzed anonymously. Finally, all primary data were collected according to STROBE (STrengthening the Reporting of OBservational studies in Epidemiology) guidelines.

\section{Study population}

We recruited 141 patients who had been undergoing continuous ambulatory PD or automated PD for at least 4 months and regularly followed up at a PD center in Chang Gung Memorial Hospital. All patients were recruited between October 1 and November 30, 2009. PD supplies (continuous ambulatory PD and automated PD solutions) were obtained from Baxter Healthcare SA, Singapore. Patients who developed dialysis-related peritonitis or active infection within 3 months before the study were excluded. The 141 patients had no history of DM, primary HPT, parathyroidectomy, or smoking habits. Age, sex, use of vitamin $\mathrm{D}_{3}$ (calcitriol), use of calcium-based phosphate binders, use of aluminum-based phosphate binders, use of calcimimetics, and clinical data were obtained from the patients' medical records.

\section{Sample collection}

Fasting blood, urine, and dialysate samples were collected on the same day between October 1 and November 30, 2009 during each patient's yearly routine examination. Residual renal function was calculated as follows: (renal normalized urea nitrogen clearance + renal normalized creatinine $[\mathrm{Cr}]$ clearance)/2. The plasma, dialysate, and urine concentrations of $\mathrm{Cr}$, serum albumin, and urea nitrogen were measured using routine laboratory methods. Protein nitrogen appearance (PNA) was normalized to body weight (nPNA). High levels of $\mathrm{SO}_{2}$, $\mathrm{NO}_{2}, \mathrm{CO}$, ozone $\mathrm{O}_{3}$, and particulate matter (PM) with an aerodynamic diameter of $<10 \mu \mathrm{m}$ and $<2.5 \mu \mathrm{m}\left(\mathrm{PM}_{10}\right.$ and $\mathrm{PM}_{2.5}$, respectively) were defined as greater than or equal to the median value of $\mathrm{SO}_{2}$ (4.4 ppb), $\mathrm{NO}_{2}$ (20.1 ppb), $\mathrm{CO}(0.53 \mathrm{ppm}), \mathrm{O}_{3}(28.7$ $\mathrm{ppb}), \mathrm{PM}_{10}\left(49.1 \mu \mathrm{g} / \mathrm{m}^{3}\right)$, and $\mathrm{PM}_{2.5}\left(29.69 \mu \mathrm{g} / \mathrm{m}^{3}\right)$. Anuria was defined as a 24-hour urine volume $<50 \mathrm{~cm}^{3}$. HPT was defined as an intact PTH (iPTH) level $\geq 180 \mathrm{pg} / \mathrm{dL}$. ${ }^{7}$ Hypoalbuminemia was defined as albumin $<3.8 \mathrm{~g} / \mathrm{dL} .{ }^{8}$

\section{Air-quality status and analysis}

To verify our hypothesis that air-pollutant levels are correlated with iPTH values in patients undergoing PD, we analyzed the database from the Taiwan Air Quality Monitoring Network operated by the Environmental Protection Administration. ${ }^{9}$ We recorded and analyzed the difference in air quality according to the patients' living areas. The referenced items included the previous 1-year (12 months) average concentrations of $\mathrm{PM}_{10}, \mathrm{PM}_{2.5}, \mathrm{SO}_{2}, \mathrm{NO}_{2}, \mathrm{CO}$, and $\mathrm{O}_{3}$. Air-pollution levels were recorded by a network of 24 monitoring stations near or in the patients' living areas throughout Taiwan. The 141 patients lived in 25 different districts. In this study, generally, data on air pollutants were obtained from the monitoring station in the same district as the patient. If patients' living districts did not have a monitoring station, the air-pollutant data from the nearest station were used (within $15 \mathrm{~km}$ ). If the patient lived between two monitoring stations, the air-pollutant data of the nearest station were selected. Terrain was also a factor; therefore, data from the nearest monitoring station and on the same side of the mountain as where patients lived were selected. The level of air pollutants was checked every hour for 1 year. As a result, we calculated the average of approximately 8,760 $(24 \times 365)$ pieces of data for every monitoring station to determine the 1 -year average level of air pollutants in this study.

\section{Statistical analysis}

The Kolmogorov-Smirnov test was used to test if variables were normally distributed. A $P$-value $>0.05$ was required to assume a normal distribution. Data are expressed in terms of medians and interquartile range in nonnormal distribution variables and as means \pm standard deviation in normal distribution variables. Comparisons between groups were performed using the Mann-Whitney test and Student's $t$-test. The frequency of categorical variables is 
expressed as numbers of patients. The $\chi^{2}$ or Fisher's exact tests were used to analyze the correlation between categorical variables. To calculate the relative correlation of HPT (iPTH $\geq 180 \mathrm{pg} / \mathrm{dL}$ ), odds ratios (ORs) and 95\% confidence intervals (CIs) were obtained using binary logistic regression models. Logarithmic conversion was made for iPTH, nPNA, high-sensitivity (hs)-CRP, and aluminum levels. In logistic regression analysis, univariate and forward logistic regression analysis were used (variables with $P<0.1$ in the univariate regression were used in the forward method) for the association between HPT and clinical variables. The following factors were investigated: high $\mathrm{SO}_{2}$ level, high $\mathrm{NO}_{2}$ level, high $\mathrm{CO}$ level, high $\mathrm{O}_{3}$ level, high $\mathrm{PM}_{10}$ level, high $\mathrm{PM}_{2.5}$ level, age, PD duration, serum $\mathrm{Cr}$ level, logarithmic nPNA level, hypoalbuminemia, serum corrected calcium level, serum phosphate level, anuria condition, logarithmic hs-CRP level, total (renal and peritoneal) Cr clearance, use of calcitriol, use of calcium-based phosphate binders, use of aluminum-based phosphate binders, logarithmic blood aluminum level, anuria, coronary artery disease, hypertension, and high education level. All the nominal variables in linear regression were dummy coding transformed. Missing data were dealt with by list-wise deletion. All statistical analyses were performed using SPSS version 12.0 for Windows (SPSS Inc, Chicago, IL, USA). A $P$-value $<0.05$ was considered statistically significant.

\section{Results}

\section{Patient characteristics}

A total of 141 patients without DM from a single PD center were enrolled in this study. Table 1 lists the characteristics of the study subjects (mean age 50 years). Of the patients, 111 were women, and their mean duration of PD was 67.3 months. Furthermore, the mean total normalized $\mathrm{Cr}$ clearance was $59.25 \mathrm{~L} /$ week $/ 1.73 \mathrm{~m}^{2}$. The median iPTH level was $166 \mathrm{pg} / \mathrm{dL}$ (71.75-525 pg/dL). The median hs-CRP level was $2.7 \mathrm{mg} / \mathrm{L}(1.14-7.29 \mathrm{mg} / \mathrm{L})$. The median concentration of $\mathrm{PM}_{10}$ was $49.1 \mu \mathrm{g} / \mathrm{m}^{3}, \mathrm{SO}_{2} 4.4 \mathrm{ppb}, \mathrm{NO}_{2} 20.1 \mathrm{ppb}, \mathrm{CO}$ $0.53 \mathrm{ppm}, \mathrm{O}_{3} 28.7 \mathrm{ppb}$, and $\mathrm{PM}_{2.5} 29.69 \mu \mathrm{g} / \mathrm{m}^{3}$. None of these patients smoked. There were 51 patients receiving vitamin $\mathrm{D}_{3}$ supplements, 131 receiving calcium-based phosphate binders, and eleven receiving aluminum-based phosphate binders; none of the 141 patients was receiving calcimimetics, lanthanum carbonate, or sevelamer.

\section{Patients undergoing PD with or without hyperparathyroidism}

We categorized our patients undergoing PD into without $(n=73)$ and with $(n=68)$ HPT (Table 2). Compared
Table I Characteristics of the PD patients

\begin{tabular}{|c|c|}
\hline Variables & $\begin{array}{l}\text { Total } \\
\text { patients }=|4|\end{array}$ \\
\hline Age (years) & $50 \pm 10.4$ \\
\hline $\mathrm{BSA}\left(\mathrm{m}^{2}\right)$ & $1.55 \pm 0.14$ \\
\hline PD duration (months) & $67.3 \pm 40.4$ \\
\hline Sex (male/female) & $30 / 111$ \\
\hline Serum $\mathrm{Cr}(\mathrm{mg} / \mathrm{dL})$ & $11.35 \pm 2.47$ \\
\hline WBC count $\left(\times 10^{9} / L\right)$ & $7.5 \pm 2.38$ \\
\hline $\mathrm{Al}(\mu \mathrm{g} / \mathrm{L})$ & $0.8(0.3-1.3)$ \\
\hline iPTH (pg/dL) & $166(71.75-525)$ \\
\hline Albumin $(\mathrm{g} / \mathrm{L})$ & $4.08 \pm 0.31$ \\
\hline nPNA (g/kg/day) & $1.03(0.88-1.17)$ \\
\hline hs-CRP (mg/L) & $2.7(1.14-7.29)$ \\
\hline $\mathrm{KT} / \mathrm{N}_{\text {urea }} \mathrm{T}$ & $2.26 \pm 0.33$ \\
\hline CCrn T (L/week/I.73 m²) & $59.25 \pm 11.13$ \\
\hline Dialysate $\mathrm{Ca}(2.5 / 3.5 \mathrm{mEq} / \mathrm{L}), \mathrm{n}$ & $60 / 81$ \\
\hline Use of calcium-based phosphate binders, $\mathrm{n}$ & 131 \\
\hline Use of aluminum-based phosphate binders, $n$ & II \\
\hline Use of calcitriol, $n$ & 51 \\
\hline Environmental $\mathrm{PM}_{10}\left(\mu \mathrm{g} / \mathrm{m}^{3}\right)$ & $49.1(44.9-56.2)$ \\
\hline Environmental $\mathrm{PM}_{2.5}\left(\mu \mathrm{g} / \mathrm{m}^{3}\right)$ & $29.69(26.44-29.88)$ \\
\hline Environmental $\mathrm{SO}_{2}(\mathrm{ppb})$ & $4.4(3.9-5.85)$ \\
\hline Environmental $\mathrm{NO}_{2}(\mathrm{ppb})$ & $20.1(16.4-22.3)$ \\
\hline Environmental CO (ppm) & $0.53(0.44-0.57)$ \\
\hline Environmental $\mathrm{O}_{3}(\mathrm{ppb})$ & $28.7(27.6-30.85)$ \\
\hline \multicolumn{2}{|c|}{ 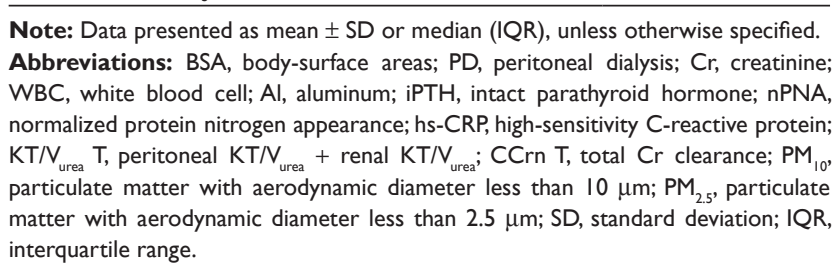 } \\
\hline
\end{tabular}

with patients without HPT, PD duration $(75.11 \pm 40.72$ vs $60.19 \pm 39.07$ months, $P=0.02)$, blood inorganic phosphate level $(5.23 \pm 1.29$ vs $4.8 \pm 1.09 \mathrm{mg} / \mathrm{dL}, P=0.03)$, environmental $\mathrm{NO}_{2}$ level (20.1 [16.3-21.0] vs 21.0 [18.02-22.9] ppb, $P=0.02)$, and environmental CO level (0.53 [0.4-0.57] vs 0.57 [0.44-0.66] ppm, $P=0.01)$ were significantly higher in patients with HPT. Residual renal function $(0.39$ [0-5.18] vs 3.33 [0-10.7], $P=0.02$ ) was lower in patients with HPT.

\section{Factors associated with hyperparathyroidism in patients undergoing PD}

To investigate the factors associated with HPT in our study patients, we used univariate binary logistic regression and multivariate logistic regression methods for analyses. High $\mathrm{SO}_{2}$ exposure, high $\mathrm{NO}_{2}$ exposure, high $\mathrm{CO}$ exposure, high $\mathrm{O}_{3}$ exposure, high $\mathrm{PM}_{10}$ exposure, high $\mathrm{PM}_{2.5}$ exposure, age, serum $\mathrm{Cr}$ level, total normalized $\mathrm{Cr}$ clearance values, $\log$ nPNA, hypoalbuminemia, blood corrected Ca level, blood inorganic phosphate level, log hs-CRP, PD duration, anuria status, coronary artery disease, use of calcitriol, use of calcium-based phosphate binders, use of aluminum-based 
Table 2 Comparison of patients with iPTH $\geq 180 \mathrm{pg} / \mathrm{dL}$ and without iPTH $<180 \mathrm{pg} / \mathrm{dL}$ hyperparathyroidism

\begin{tabular}{|c|c|c|c|}
\hline Variables & iPTH $<180 \mathrm{pg} / \mathrm{dL}(\mathrm{n}=73)$ & $\mathrm{iPTH} \geq 180 \mathrm{pg} / \mathrm{dL}(\mathrm{n}=68)$ & $P$-value \\
\hline Age (years) & $51.06 \pm 11.07$ & $48.94 \pm 9.73$ & 0.22 \\
\hline PD duration (months) & $60.19 \pm 39.07$ & $75.1 I \pm 40.72$ & 0.02 \\
\hline Residual renal function $(\mathrm{mL} / \mathrm{min})$ & $3.33(0-10.7)$ & $0.39(0-5.18)$ & 0.02 \\
\hline Sex, male/female $(n)$ & $16 / 57$ & $14 / 54$ & 0.99 \\
\hline BUN (mg/dL) & $60.54 \pm 15.25$ & $58.06 \pm 16.96$ & 0.36 \\
\hline Serum Cr (mg/dL) & $11.36 \pm 2.59$ & $11.35 \pm 2.35$ & 0.99 \\
\hline WBC count $\left(\times 10^{9} / L\right)$ & $7.62 \pm 2.49$ & $7.37 \pm 2.25$ & 0.53 \\
\hline $\mathrm{Al}(\mu \mathrm{g} / \mathrm{L})$ & $0.8(0.25-1.3)$ & $0.8(0.4-1.45)$ & 0.6 \\
\hline Hypoalbuminemia, n & $9 / 73(12.3 \%)$ & $18 / 68(26.5 \%)$ & 0.05 \\
\hline nPNA (g/kg/day) & $1.04 \pm 0.2$ & $1.04 \pm 0.22$ & 0.86 \\
\hline $\mathrm{Ca}(\mathrm{mg} / \mathrm{dL})$ & $10.24 \pm 0.86$ & $10.21 \pm 0.87$ & 0.82 \\
\hline Phosphate (mg/dL) & $4.8 \pm 1.09$ & $5.23 \pm 1.29$ & 0.03 \\
\hline Dialysate Ca (2.5/3.5 mEq/L) & $30 / 43$ & $30 / 38$ & 0.736 \\
\hline hs-CRP (mg/L) & $2.17(1.11-5.96)$ & $3(1.27-9.13)$ & 0.35 \\
\hline $\mathrm{KT} / \mathrm{V}_{\text {urea }} \mathrm{T}$ & $2.23 \pm 0.34$ & $2.29 \pm 0.33$ & 0.25 \\
\hline CCrn T (L/week/I.73 m²) & $58.56 \pm 11.47$ & $59.98 \pm 10.79$ & 0.45 \\
\hline Environmental $\mathrm{SO}_{2}(\mathrm{ppb})$ & $4.4(3.9-5.9)$ & $5.2(4.0-5.75)$ & 0.39 \\
\hline Environmental $\mathrm{NO}_{2}(\mathrm{ppb})$ & $20.1(|6.3-2| .0)$ & $21.0(18.02-22.9)$ & 0.02 \\
\hline Environmental CO (ppm) & $0.53(0.4-0.57)$ & $0.57(0.44-0.66)$ & 0.01 \\
\hline Environmental $\mathrm{O}_{3}(\mathrm{ppb})$ & $29.0(28.2-3 \mid .2)$ & $28.7(26.4-29.22)$ & 0.06 \\
\hline Environmental $\mathrm{PM}_{10}\left(\mu \mathrm{g} / \mathrm{m}^{3}\right)$ & $49.4(44.9-56.2)$ & $48(44.9-58.45)$ & 0.8 \\
\hline Environmental $\mathrm{PM}_{2.5}\left(\mu \mathrm{g} / \mathrm{m}^{3}\right)$ & $29.69(26.44-29.88)$ & $27.56(26.5 \mathrm{I}-29.85)$ & 0.35 \\
\hline
\end{tabular}

Notes: Data are expressed as median (interquartile range) in nonnormal distribution variables, and as means \pm standard deviation in normal distribution variables, unless otherwise specified.

Abbreviations: iPTH, intact parathyroid hormone; PD, peritoneal dialysis; BUN, blood urea nitrogen; Cr, creatinine; WBC, white blood cell; Al, aluminum; nPNA, normalized protein nitrogen appearance; hs-CRP, high-sensitivity C-reactive protein; KT/ $\mathrm{V}_{\text {urea }} \mathrm{T}$, peritoneal $\mathrm{KT} / \mathrm{V}_{\text {urea }}+$ renal $\mathrm{KT} / \mathrm{V}_{\text {urea }}$; $\mathrm{CCrn} \mathrm{T}$, total $\mathrm{Cr}$ clearance; $\mathrm{PM} \mathrm{I}_{10}$, particulate matter with aerodynamic diameter less than $10 \mu \mathrm{m} ; \mathrm{PM}_{2.5}$, particulate matter with aerodynamic diameter less than $2.5 \mu \mathrm{m}$.

phosphate binders, hypertension, high education level, and $\log \mathrm{Al}$ were investigated as clinical variables. Table 3 shows that in univariate binary logistic regression, high $\mathrm{NO}_{2}$ exposure (OR 2.3, 95\% CI 1.16-4.57; $P=0.01$ ), high CO exposure (OR 2.437, 95\% CI 1.231-4.823; $P=0.01$ ), blood inorganic phosphate levels (OR 1.36, 95\% CI 1.02-1.82; $P=0.03$ ), hypoalbuminemia (OR 2.56, 95\% CI 1.06-6.18; $P=0.03$ ), PD duration (OR 1.01, 95\% CI 1.001-1.018; $P=0.03$ ), use of calcitriol (OR 6.83, 95\% CI 3.12-14.96; $P<0.001$ ), use of aluminum-based phosphate binders (OR 12.41, 95\% CI 1.54-99.81; $P=0.01$ ), and anuria status (OR 2.15, 95\% CI $1.11-4.34 ; P=0.02$ ) were positively associated with HPT. Furthermore, in the forward model of binary logistic regression, after adjustment for related factors, high $\mathrm{CO}$ exposure (OR 3.226, 95\% CI 1.42-7.28; $P=0.005$ ), blood inorganic phosphate levels (OR 1.66, 95\% CI 1.17-2.37; $P=0.005$ ), hypoalbuminemia (OR 3.76, 95\% CI 1.29-10.94; $P=0.01$ ), and use of calcitriol (OR 8.25, 95\% CI 3.43-19.85; $P<0.001$ ) were positively associated with HPT.

\section{Factors associated with high and low CO-level} exposure in patients undergoing PD

Patients were divided into two subgroups (low, $\mathrm{n}=80$; high, $\mathrm{n}=61$ ) according to the median environmental $\mathrm{CO}$ value
(0.53 ppm). Compared with low CO-exposure levels, patients exposed to high CO levels had higher iPTH levels (281 [99-603] vs 130 [67.4-407.25] pg/dL, $P=0.04)$. In addition, age (49.17 \pm 10.31 vs $51.18 \pm 10.64$ years, $P=0.26$ ), PD duration (62.4 \pm 38.02 vs $73.93 \pm 42.82$ months, $P=0.09)$, total $C r$ clearance $\left(58.06 \pm 10.3\right.$ vs $60.8 \pm 12.04 \mathrm{~L} /$ week $\left./ 1.73 \mathrm{~m}^{2}, P=0.15\right)$, nPNA (1.025 [0.88-1.15] vs 1.04 [0.9-1.2] g/kg/day, $P=0.7)$, $\mathrm{Ca}(10.24 \pm 0.87$ vs $10.21 \pm 0.87 \mathrm{mg} / \mathrm{dL}, P=0.88)$, phosphate (5.07 \pm 1.27 vs $4.92 \pm 1.12 \mathrm{mg} / \mathrm{dL}, P=0.47)$, hs-CRP (2.07 [1.12$6.02]$ vs $3.42[1.21-9.99] \mathrm{mg} / \mathrm{L}, P=0.17), \mathrm{KT} / \mathrm{V}_{\text {urea }} \mathrm{T}(2.24 \pm 0.3$ vs $2.29 \pm 0.37, P=0.39)$, white blood cell count $(7.43 \pm 2.58$ vs $\left.7.6 \pm 2.09 \times 10^{9} / \mathrm{L}, P=0.65\right)$, and hemoglobin $(10.06 \pm 1.41 \mathrm{vs}$ $10.18 \pm 1.62 \mathrm{~g} / \mathrm{dL}, P=0.64)$ were not significantly different in patients living in low and high CO-exposure areas (Figure 1).

\section{Discussion}

In this study, we showed that after adjustment for related risk factors, ambient $\mathrm{CO}$ level was significantly positively associated with SHPT in patients undergoing PD who did not have DM.

In patients with CKD, with the decline in renal function and loss of renal $1 \alpha$-hydroxylase, the concentration of the active form vitamin $\mathrm{D}$ also decreases. ${ }^{10} \mathrm{Vitamin} \mathrm{D}$ deficiency is a known risk factor for the development of SHPT in patients 
Table 3 Logistic regression analysis between hyperparathyroidism (iPTH $\geq 180 \mathrm{pg} / \mathrm{dL}$ ) and clinical variables $(\mathrm{n}=|\mathrm{I}|$ )

\begin{tabular}{|c|c|c|c|c|}
\hline \multirow[t]{2}{*}{ Variables } & \multicolumn{4}{|c|}{ Hyperparathyroidism (iPTH $\geq 180 \mathrm{pg} / \mathrm{dL}$ ) } \\
\hline & $\begin{array}{l}\text { Univariate logistic } \\
\text { regression, OR }(95 \% \mathrm{Cl})\end{array}$ & $P$-value & $\begin{array}{l}\text { Forward multivariate logistic } \\
\text { regression, OR }(95 \% \mathrm{CI})\end{array}$ & $P$-value \\
\hline High $\mathrm{SO}_{2}(\mathrm{ppb})$ exposure & $1.44(0.74-2.8)$ & 0.27 & & \\
\hline High $\mathrm{NO}_{2}(\mathrm{ppb})$ exposure & $2.3(1.16-4.57)$ & 0.01 & & \\
\hline High CO (ppm) exposure & $2.43(1.23-4.82)$ & 0.01 & $3.22(1.42-7.28)$ & 0.005 \\
\hline $\mathrm{High}_{3}(\mathrm{ppb})$ exposure & $0.77(0.39-1.49)$ & 0.44 & & \\
\hline High $\mathrm{PM}_{10}$ exposure & $0.578(0.296-1.126)$ & 0.10 & & \\
\hline High $\mathrm{PM}_{2.5}$ exposure & $0.726(0.36-1.44)$ & 0.36 & & \\
\hline Age (years) & $0.98(0.94-1.01)$ & 0.22 & & \\
\hline Male sex & $0.92(0.4 \mathrm{I}-2.07)$ & 0.84 & & \\
\hline Serum $\mathrm{Cr}(\mathrm{mg} / \mathrm{dL})$ & $0.99(0.87-1.14)$ & 0.99 & & \\
\hline CCrn T (L/week/I.73 m²) & $1.01(0.98-1.04)$ & 0.44 & & \\
\hline Log nPNA (g/kg/day) & $1.14(0.25-5.1)$ & 0.86 & & \\
\hline Hypoalbuminemia & $2.56(1.06-6.18)$ & 0.03 & $3.76(1.29-10.94)$ & 0.015 \\
\hline $\mathrm{Ca}(\mathrm{mg} / \mathrm{dL})$ & $0.95(0.65-1.40)$ & 0.82 & & \\
\hline Phosphate (mg/dL) & $1.36(1.02-1.82)$ & 0.03 & $1.66(1.17-2.37)$ & 0.005 \\
\hline Log hs-CRP (mg/dL) & $1.34(0.72-2.5)$ & 0.35 & & \\
\hline PD duration (months) & $1.01(1.001-1.018)$ & 0.03 & & \\
\hline Use of calcitriol & $6.83(3.12-14.96)$ & $<0.001$ & $8.25(3.43-19.85)$ & $<0.001$ \\
\hline Use of calcium-based phosphate binders & $1.43(0.38-5.31)$ & 0.59 & & \\
\hline Use of aluminum-based phosphate binders & I2.4I (I.54-99.8I) & 0.01 & & \\
\hline Anuria & $2.15(1.11-4.34)$ & 0.02 & & \\
\hline CAD & $0.53(0.047-5.98)$ & 0.60 & & \\
\hline HTN & $0.79(0.4-1.55)$ & 0.5 & & \\
\hline High education level & $1.16(0.59-2.25)$ & 0.65 & & \\
\hline $\log \mathrm{Al}(\mu \mathrm{g} / \mathrm{L})$ & $1.23(0.6-2.52)$ & 0.56 & & \\
\hline Dialysate Ca (mEq/L) & $0.88(0.45-1.72)$ & 0.717 & & \\
\hline
\end{tabular}

Notes: High $\mathrm{SO}_{2}$ exposure represented as $\geq$ mean value of $4.4 \mathrm{ppb}$; high $\mathrm{NO}_{2}$ exposure represented as $\geq$ mean value of $20.1 \mathrm{ppb}$; high $\mathrm{CO}$ exposure represented as $\geq$ mean value of $0.53 \mathrm{ppm}$; high $\mathrm{O}_{3}$ exposure represented as $\geq$ mean value of $28.7 \mathrm{ppb}$; high $\mathrm{PM}_{10}$ exposure represented as $\geq$ median value of $49.1 \mu \mathrm{g} / \mathrm{m}^{3}$; high $\mathrm{PM} \mathrm{M}_{2.5}$ exposure represented as $\geq$ median value of $29.69 \mu \mathrm{g} / \mathrm{m}^{3}$; anuria defined as 24 -hour urine volume $<50 \mathrm{~cm}^{3}$.

Abbreviations: $\mathrm{iPTH}$, intact parathyroid hormone; $\mathrm{PM}_{10}$, particulate matter with aerodynamic diameter less than $10 \mu \mathrm{m}$; $\mathrm{PM}$, particulate matter with aerodynamic diameter less than $2.5 \mu \mathrm{m}$; $\mathrm{Cr}$, creatinine; $\mathrm{CCrn} \mathrm{T}$, total $\mathrm{Cr}$ clearance; nPNA, normalized protein nitrogen appearance; hs-CRP, high-sensitivity C-reactive protein; PD, peritoneal dialysis; CAD, coronary arterial disease; HTN, hypertension.

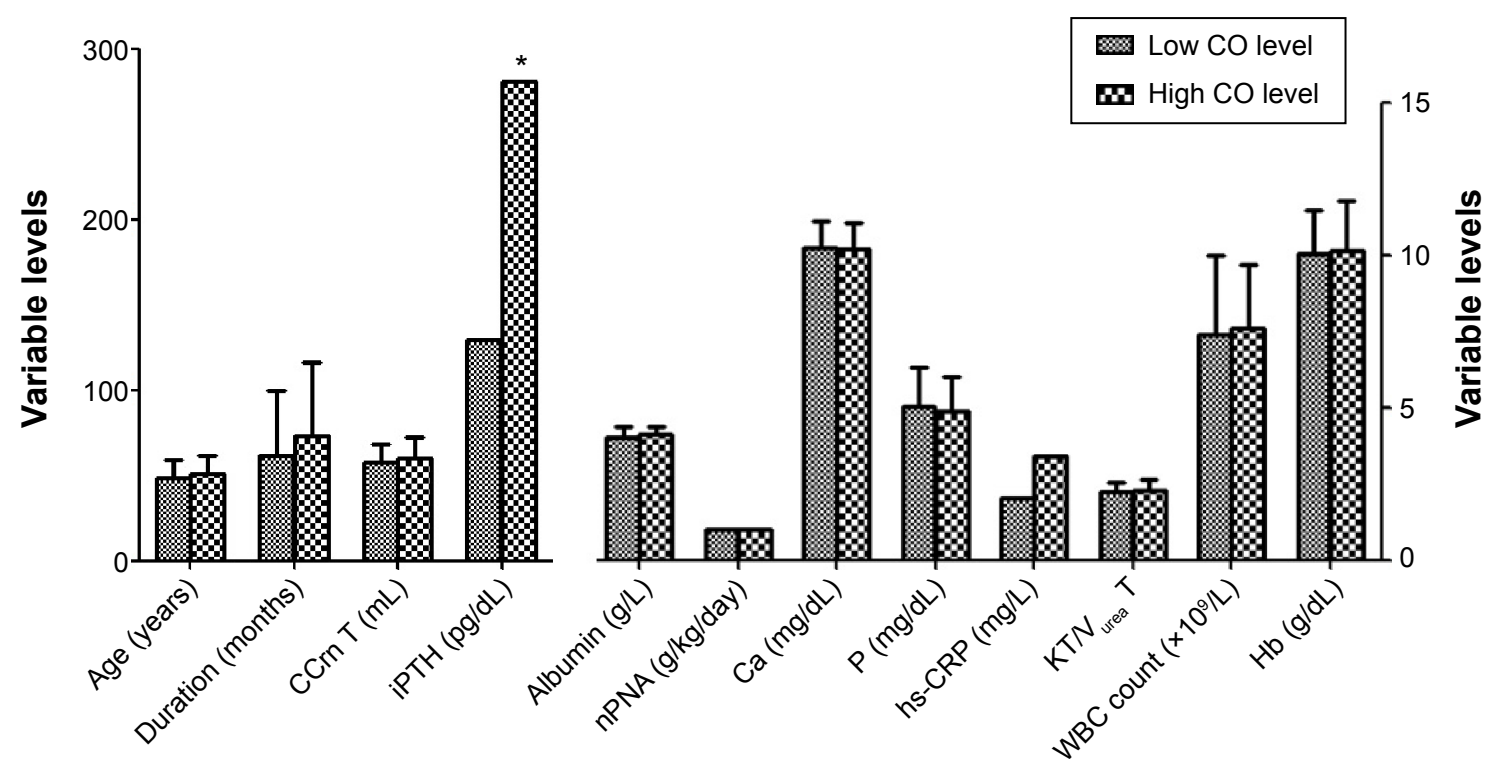

Figure I Comparison of patients living in high and low CO-exposure areas.

Notes: Patients living in high CO-exposure areas had higher iPTH levels than patients living in low CO-exposure areas. High and low CO exposures were separated by a mean value of $0.53 \mathrm{pPm}$. iPTH, nPNA and hs-CRP are represented as median values, and the others are represented as mean values. $* P<0.05$.

Abbreviations: iPTH, intact parathyroid hormone; nPNA, normalized protein nitrogen appearance; P, phosphate; hs-CRP, high-sensitivity C-reactive protein; CCrn T, total creatinine clearance; $\mathrm{KT} / \mathrm{V}_{\text {urea }} \mathrm{T}$, peritoneal $\mathrm{KT} / \mathrm{V}_{\text {urea }}+$ renal $\mathrm{KT} / \mathrm{V}_{\text {urea; }}$ WBC, white blood cell; Hb, hemoglobin. 
with chronic renal failure. SHPT has a complex pathogenesis primarily caused by a decrease in calcitriol and anomalies in regulation of serum calcium and phosphorus levels. In patients with chronic renal failure, serum levels of $1,25(\mathrm{OH})_{2} \mathrm{D}$ were positively correlated with estimated $\mathrm{Cr}$ clearance. ${ }^{11}$ However, it is interesting that in 1982, Lambert et al showed that without vitamin D purveyance, a serum level of calcitriol was detected in five adult patients undergoing anephric hemodialysis. ${ }^{12}$ This phenomenon suggests the existence of extrarenal production of calcitriol. In an in vitro study, calcitriol was synthesized by human decidua and placenta, ${ }^{13}$ rat placenta tissue, ${ }^{14}$ human bone cell cultures, ${ }^{15}$ human macrophages, ${ }^{16}$ and isolated calvarial cells. ${ }^{17}$ Additionally, several studies identified another pathway for synthesis of calcitriol in the skin. ${ }^{18,19}$ Working in concert with these studies, Krause recently pointed out that in long-term patients undergoing hemodialysis, the use of sunsimulating artificial lamps could significantly increase blood calcitriol and calcidiol levels. ${ }^{20}$ Krause also pointed out that increased skin ultraviolet (UV)-B radiation could improve the residual capacity of the kidneys' endocrine function in patients with CKD to produce more $1,25(\mathrm{OH})_{2} \mathrm{D}_{3}$.

There are many exogenous factors affecting the dermal production of cholecalciferol, such as sunlight, air pollution, sunscreen, clothing, latitude, and season. ${ }^{21}$ The most notable of these factors in urbanized society is air pollution. In many industrialized cities, air pollution can absorb or obstruct UVB, such as absorption by nitrated and aromatic aerosols, nitrated aromatic gases and benzaldehyde, which are coexhausted with $\mathrm{CO}$, were hypothesized to have reduced observed downward global UVA and UVB irradiance, ${ }^{22}$ thus reducing the dermal photosynthesis of precholecalciferol. This may result in an increased risk of vitamin D deficiency in people who live in polluted cities. ${ }^{21}$ It has been previously raised that air-pollution exposure can lead to a variety of complications such as increased risk of cardiovascular events, ${ }^{23-25}$ cerebrovascular accidents, ${ }^{26,27}$ specific cancers, ${ }^{28}$ and respiratory systemic diseases..$^{23,24}$ Agarwal et al and Hosseinpanah et al showed that even healthy women or children living in areas of high atmospheric pollution had higher PTH levels than those living in low-pollution areas. .,6 $^{5}$

The most likely explanation is that UVB radiation is absorbed or obstructed by air pollution from industrial or vehicular sources and reduces dermal vitamin D synthesis. ${ }^{21,29}$ Neither Agarwal et al nor Hosseinpanah et al determined what the main chemical particles are that affect vitamin D synthesis. However, in a recent animal study, Feger et al showed that by decreasing transcript levels of Cyp27b1, CO plays a role in decreasing $1,25(\mathrm{OH})_{2} \mathrm{D}_{3}$ synthesis. ${ }^{30}$ To the best of our knowledge, direct evidence on the correlation between air pollution and parathyroid dysfunction is limited. Based on the cited studies, except for the relationship between the kidneys and active vitamin D synthesis, we could make an inference that via the pathway of decreasing residual renal and extrarenal active vitamin D synthesis, high ambient $\mathrm{CO}$ levels could be associated with increasing PTH synthesis in our patients (Figure 2).

We also found that hypoalbuminemia was correlated with high PTH levels when it was selected as an adjustment factor in the stepwise logistic regression analysis (Table 3). However, in patients with chronic renal failure, Ishimura et $\mathrm{al}^{11}$ showed that levels of $1,25(\mathrm{OH}) 2 \mathrm{D}_{3}, 1,25(\mathrm{OH}) 2 \mathrm{D}_{3}$, and $25(\mathrm{OH}) 2 \mathrm{D}_{3}$ were positively correlated with serum albumin levels. In an animal study, dogs with hypoalbuminemia had high PTH levels and low $25(\mathrm{OH}) 2 \mathrm{D}_{3}$ concentrations. ${ }^{31}$ The positive correlation between serum vitamin D-binding protein and serum albumin level ${ }^{32}$ and the previously cited studies could support our observations.

This study had some limitations. First, this was a smallpopulation study to investigate such a large number of variables. Second, we did not check $25(\mathrm{OH}) \mathrm{D}_{3}$ or $1,25(\mathrm{OH})_{2}$ $\mathrm{D}_{3}$ serum levels because of the cross-sectional study design. The positive correlation between air pollution and vitamin $\mathrm{D}$ levels in patients undergoing PD is worth further evaluation. Third, we had little information on the range of patient activities and indoor air quality of the studied patients. Fourth, the information on the patients' sunlight exposure per day was limited. Fifth, we are uncertain whether the previous 1-year average air-quality data for the patients' living areas published by the Taiwan Environmental Protection Administration was sufficiently objective to represent the air quality

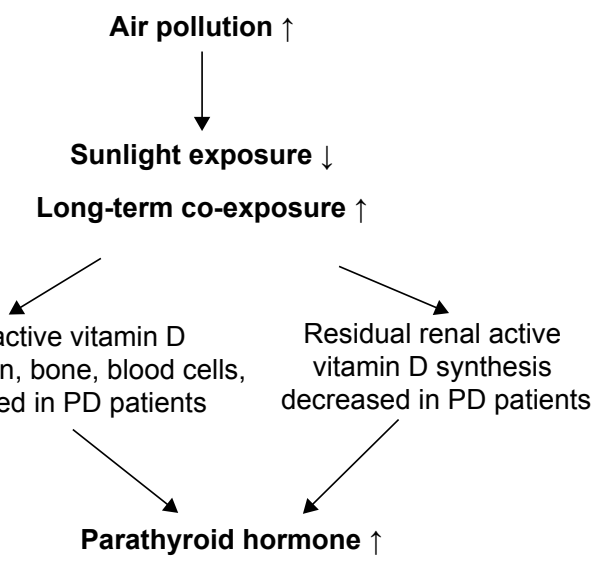

Figure 2 Inference of the correlation between air pollution, $\mathrm{CO}$, and parathyroid hormone.

Abbreviations: $\downarrow$, decrease; $\uparrow$, increase; PD, peritoneal dialysis. 
around the patients. However, according to air-pollution studies of short-term ${ }^{33}$ and long-term ${ }^{34}$ exposure, we believe that our 1-year average air-pollution concentration data were adequately representative for this study.

\section{Conclusion}

In conclusion, the findings of this cross-sectional study indicated the presence of an association between ambient $\mathrm{CO}$ and SHPT in patients undergoing PD who did not have DM. Therefore, poor environmental air quality may be a risk factor for deterioration of SHPT in patients undergoing PD.

\section{Acknowledgments}

The authors thank the members of the Statistics Center in Chang Gung Memorial Hospital for their invaluable and dedicated assistance, and the members of the Peritoneal Dialysis Center in Chang Gung Memorial Hospital for their invaluable and dedicated assistance.

\section{Disclosure}

The authors report no conflicts of interest in this work.

\section{References}

1. Couser WG, Remuzzi G, Mendis S, Tonelli M. The contribution of chronic kidney disease to the global burden of major noncommunicable diseases. Kidney Int. 2011;80(12):1258-1270.

2. Owda A, Elhwairis H, Narra S, Towery H, Osama S. Secondary hyperparathyroidism in chronic hemodialysis patients: prevalence and race. Ren Fail. 2003;25(4):595-602.

3. Slatopolsky E, Brown A, Dusso A. Pathogenesis of secondary hyperparathyroidism. Kidney Int Suppl. 1999;73:S14-S19.

4. Douthat WG, Castellano M, Berenguer L, et al. High prevalence of secondary hyperparathyroidism in chronic kidney disease patients on dialysis in Argentina. Nefrologia. 2013;33(5):657-666.

5. Agarwal KS, Mughal MZ, Upadhyay P, Berry JL, Mawer EB, Puliyel JM. The impact of atmospheric pollution on vitamin $D$ status of infants and toddlers in Delhi, India. Arch Dis Child. 2002;87(2):111-113.

6. Hosseinpanah F, Pour SH, Heibatollahi M, Moghbel N, Asefzade S, Azizi F. The effects of air pollution on vitamin D status in healthy women: a cross sectional study. BMC Public Health. 2010;10:519.

7. Nakai S, Akiba T, Kazama J, et al. Effects of serum calcium, phosphorous, and intact parathyroid hormone levels on survival in chronic hemodialysis patients in Japan. Ther Apher Dial. 2008;12(1):49-54.

8. Fouque D, Kalantar-Zadeh K, Kopple J, et al. A proposed nomenclature and diagnostic criteria for protein-energy wasting in acute and chronic kidney disease. Kidney Int. 2008;73(4):391-398.

9. Environmental Protection Administration. Taiwan Air Quality Monitoring Network. Available from: http://taqm.epa.gov.tw/taqm/en/default.aspx. Accessed August 25, 2014.

10. Martinez I, Saracho R, Montenegro J, Llach F. A deficit of calcitriol synthesis may not be the initial factor in the pathogenesis of secondary hyperparathyroidism. Nephrol Dial Transplant. 1996;11 Suppl 3:22-28.

11. Ishimura E, Nishizawa Y, Inaba M, et al. Serum levels of 1,25-dihydroxyvitamin D, 24,25-dihydroxyvitamin D, and 25-hydroxyvitamin $\mathrm{D}$ in nondialyzed patients with chronic renal failure. Kidney Int. 1999;55(3):1019-1027.

12. Lambert PW, Stern PH, Avioli RC, et al. Evidence for extrarenal produc-

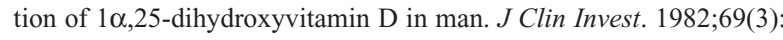
$722-725$.
13. Weisman Y, Harell A, Edelstein S, David M, Spirer Z, Golander A. 1 1,25 Dihydroxyvitamin D3 and 24,25-dihydroxyvitamin D3 in vitro synthesis by human decidua and placenta. Nature. 1979;281(5729):317-319.

14. Tanaka Y, Halloran B, Schnoes HK, DeLuca HF. In vitro production of 1,25-dihydroxyvitamin D3 by rat placental tissue. Proc Natl Acad Sci U S A. 1979;76(10):5033-5035.

15. Howard GA, Turner RT, Sherrard DJ, Baylink DJ. Human bone cells in culture metabolize 25-hydroxyvitamin D3 to 1,25-dihydroxyvitamin D3 and 24,25-dihydroxyvitamin D3. J Biol Chem. 1981;256(15): $7738-7740$.

16. Dusso AS, Finch J, Brown A, et al. Extrarenal production of calcitriol in normal and uremic humans. J Clin Endocrinol Metab. 1991;72(1): $157-164$.

17. Turner RT, Puzas JE, Forte MD, et al. In vitro synthesis of $1 \alpha, 25$ dihydroxycholecalciferol and 24,25-dihydroxycholecalciferol by isolated calvarial cells. Proc Natl Acad Sci U S A. 1980;77(10):5720-5724.

18. Lehmann B, Genehr T, Knuschke P, Pietzsch J, Meurer M. UVB-induced conversion of 7-dehydrocholesterol to $1 \alpha, 25$-dihydroxyvitamin D3 in an in vitro human skin equivalent model. J Invest Dermatol. 2001;117(5): 1179-1185.

19. Zehnder D, Bland R, Williams MC, et al. Extrarenal expression of 25-hydroxyvitamin $\mathrm{D}_{3}-1 \alpha$-hydroxylase. J Clin Endocrinol Metab. 2001; 86(2):888-894.

20. Krause R. Vitamin D and UV exposure in chronic kidney disease. Dermatoendocrinol. 2013;5(1):109-116.

21. Holick MF. Environmental factors that influence the cutaneous production of vitamin D. Am J Clin Nutr. 1995;61(3 Suppl):638S-645S.

22. Jacobson MZ. Isolating nitrated and aromatic aerosols and nitrated aromatic gases as sources of ultraviolet light absorption. J Geophys Res Atmos. 1999;104(D3):3527-3542.

23. Dockery DW, Pope CA 3rd, Xu X, et al. An association between air pollution and mortality in six U.S. cities. N Engl J Med. 1993;329(24): $1753-1759$.

24. Dockery DW, Stone PH. Cardiovascular risks from fine particulate air pollution. N Engl J Med. 2007;356(5):511-513.

25. Gan WQ, Davies HW, Koehoorn M, Brauer M. Association of long-term exposure to community noise and traffic-related air pollution with coronary heart disease mortality. Am J Epidemiol. 2012;175(9):898-906.

26. Mateen FJ, Brook RD. Air pollution as an emerging global risk factor for stroke. JAMA. 2011;305(12):1240-1241.

27. Tsai SS, Goggins WB, Chiu HF, Yang CY. Evidence for an association between air pollution and daily stroke admissions in Kaohsiung, Taiwan. Stroke. 2003;34(11):2612-2616.

28. Raaschou-Nielsen O, Andersen ZJ, Hvidberg M, et al. Lung cancer incidence and long-term exposure to air pollution from traffic. Environ Health Perspect. 2011;119(6):860-865.

29. Calabrese EJ. The influence of ambient ozone on the incidence of bone fractures especially among the elderly. Med Hypotheses. 1979;5(2): 201-207.

30. Feger M, Fajol A, Lebedeva A, et al. Effect of carbon monoxide donor CORM-2 on vitamin D3 metabolism. Kidney Blood Press Res. 2013;37(4-5):496-505.

31. Gow AG, Else R, Evans H, Berry JL, Herrtage ME, Mellanby RJ. Hypovitaminosis D in dogs with inflammatory bowel disease and hypoalbuminaemia. J Small Anim Pract. 2011;52(8):411-418.

32. Brown I, Sood A, Carter ND. Vitamin D binding globulin levels and affinity in various clinical conditions. J Clin Pathol. 1980; 33(10):966-970.

33. Katsouyanni K, Touloumi G, Spix C, et al. Short-term effects of ambient sulphur dioxide and particulate matter on mortality in 12 European cities: results from time series data from the APHEA project. Air Pollution and Health: a European Approach. BMJ. 1997;314(7095):1658-1663.

34. Panasevich S, Leander K, Rosenlund M, et al. Associations of long- and short-term air pollution exposure with markers of inflammation and coagulation in a population sample. Occup Environ Med. 2009;66(11):747-753. 


\section{Publish your work in this journal}

Therapeutics and Clinical Risk Management is an international, peerreviewed journal of clinical therapeutics and risk management, focusing on concise rapid reporting of clinical studies in all therapeutic areas, outcomes, safety, and programs for the effective, safe, and sustained use of medicines. This journal is indexed on PubMed Central, CAS,

EMBase, Scopus and the Elsevier Bibliographic databases. The manuscript management system is completely online and includes a very quick and fair peer-review system, which is all easy to use. Visit $\mathrm{http}: / / \mathrm{www}$.dovepress.com/testimonials.php to read real quotes from published authors.

Submit your manuscript here: http://www.dovepress.com/therapeutics-and-clinical-risk-management-journal 